\title{
コンクリートの破面解析に用いる主要特徴量に関する実験的検討 EXPERIMENTAL STUDY ON MAJOR PARAMETERS OF FRACTOGRAPHY FOR CONCRETE
}

\author{
佐藤あゆみ*, 山田寛次**, 石山智*** \\ Ayumi SATOH, Kanji YAMADA and Satoru ISHIYAMA
}

\begin{abstract}
This study discusses experimentally the relationship between the major nine parameters used for fractography of concrete and the mechanical properties of the specimens. The authors employed 18 types of specimens made of different mix proportions of concrete with a different maximum size, a different quantity, a different fineness modulus and the brand of aggregates, but the water-to-cement ratio is about the same. They include not only monolithic specimens made of cement paste or mortar, but also jointed specimens with placing joint at the center. The authors obtained mechanical properties and fractographic parameters with testing and analyzing such various types of concrete specimens. The findings are as follows:

1. The nine fractographic parameters are closely related to each other reflecting the extent of crack paths and the depth of fracture process zone, though they have the different viewpoints with focusing on the extreme points (i.e., the height or its derivatives), the increase of the length or the area from the projected ones, or the local curvature.

2. The most consistent fractographic parameter to the mechanical properties is $R_{S}$ (the ratio of the fractured surface to the projected one) among the parameters analyzed in this study, which is considered to be the results of the extent of crack paths and the depth of fracture process zone. Other 8 parameters are closely related parameters to $R_{S}$.
\end{abstract}

Keywords: Concrete, Fractography, Fracture Energy, Fractal

コンクリート，破面解析，破壊エネルギー，フラクタル

\section{1. はじめに}

コンクリートは国土の基盤構築にとって最も重要な建設材料の一 つであり, その時々の社会から多くの課題が要求されてきた。構造 に関するものとして, 近年では, 都市の高層化に対する材料強度向 上，耐震性や破壊時の安全性向上のための勒性向上，また経年劣化 に伴う補修時の界面付着性能向上などが，コンクリートの材料的課 題として挙げられる。実はこれら課題は材料技術的には同じひびわ れ伸展抵抗性に関しており, その解決にはひび割れ伸展に関する本 質的な研究が有効である。その際，ひびわれ伸展の結果である破壊 面に着目し，破面解析によって検討を行うことが有力な方法の一つ であると考えられる。

破面解析は，主に金属材料の破断面を調查して，破壊機構や破壞 原因の究明を行い問題の解決を図るものとして発達した ${ }^{1)}$ 。コンク リートの場合, 金属に比し極めて非均質であるため, その適用に注 意を要する。つまり，コンクリートでは破断に先立ち安定な微細ひ び割れによる破壊進行領域(FPZ)が生じ, ある瞬間それら微細ひび割 れを縫うようなひび割れとなって破面を形成する ${ }^{2)}$ 。このように複
雑なプロセスを含むが，リガメント領域の非均質性は破壊エネルギ 一の増加をもたらし，非均質性により迂回するひび割れ伸展により 形成される破面の特徵量に間接的に反映されると考えられる。従っ て最終的な破面に着目しても破壊エネルギーとの関係を論じられる と考えられる。さらに強度は破壊途上で生じるが，その時のひび割 れの状態が複雑なほど破壊強度に達した実面積が大きいことを意味 し，その形態は最終的な破面に残っている。これらのことから，コ ンクリートにおいて力学特性值と破面解析を結びつけようとする既 往の研究は多い。表 1 に, 既往の研究で用いられた代表的な特徵量 の名称とそれを扱った文献名 ${ }^{3 \sim 30)}$ を示す。このように，コンクリー トの破面は不規則な形状を示すため, フラクタル次元のように波形 の単純化を扱う研究が多いことが分かる。これらの研究では単一の 特徴量を元に説明しようとしており，様々な特徽量を元にその相互 関係を包括的に調心゙た例は少ない。またそれら既往の研究では，特 定の調合による一体打ちコンクリートの破面を対象にしており，本 研究で対象と寸るような異なる種類と粒度の骨材を使用し, また打 継ぎなどの界面を有するなど,幅広い試験体を対象にした例はない。

\footnotetext{
* 熊本大学自然科学研究科環境共生工学専攻 助教・博士 (工学)

** 秋田県立大学システム科学技術学部建築環境システム学科 教授・博士 (工学)

*** 秋田県立大学システム科学技術学部建築環境システム学科 助教 $\cdot$ 博士 $($ 工学 $)$
}

Research Assoc., Architectural and Civil Engineering, Graduate School of Science and Technology, Kumamoto University

Prof., Dept. of Architecture and Environment Systems, Faculty of Systems Science and Technology, Akita Prefectural University

Research Assoc., Dept. of Architecture and Environment Systems, Faculty of Systems Science and Technology, Akita Prefectural University 
以上の背景の元で, 著者らは, 破面解析によってひび割れ伸展一 の抵抗(強度)とそれに伴う勒性発現の本質に迫ることを目的に研究 を進めている。本研究では, コンクリートの破面解析で求められる 特徴量がどのように材料の力学特性値と関連するのかについて実験 的な考察を行う。まず，コンクリートにおける既往の破面解析で使 用された特徴量をレビューし，その中から強度と勒性に深く関係す ると考えられる主要な特徴量を 9 つ選択した。その後, これらを一 体打ち試験体(18 種類)および打継ぎ試験体(25 種類)により求め, そ れらの相互関係を実験的に明らかにし, その特徴量がどのような関 係で力学特性值と結びつくかを考察する。

\section{2. 既往の研究}

破面の特徴量として, 破面の増分に関する割増率があり, 例えば 面積割増率 $\mathrm{R}_{\mathrm{S}}$ は実測した破面の表面積を投影面積で除することで 得られる特徴量である ${ }^{3 \sim 8)}$ 。Chupanit $ら^{8)}$ は骨材種類, 骨材寸法を変 えたコンクリートのコンパクトテンション試験を行い, 破壊エネル ギーと $\mathrm{R}_{\mathrm{S}}$ との間に比例関係があると報告している。割増率は比較的 簡便に評価できるが，測定解像度への依存が大きく, 測定間隔を小 さくするほど破面中の細かい凹凸が観察され，同一破面であっても 特徵量は大きくなってしまうことが欠点である。

測定間隔の影響を受けにくく, 同様の測定法で評価できる特徵量 にフラクタル次元がある ${ }^{3,4,7,9 \sim 19)}$ 。フラクタル次元は破面の自己相 似性に着目して, 複数の測定間隔の結果を用いて算出され, 次元が 大きいほど破面が複雑であることを表す特徵量である ${ }^{31)}$ 。フラクタ ル次元と機械的性質との関連を論じた研究として, 三橋らの研究 ${ }^{4)}$ が先駆的で，フラクタル次元の測定手順を比較したほか，骨材粒径 の異なるコンクリートの破面の複雑さが破壊エネルギーと直接的な 関係にあることを明らかにしている。

その他, JIS 規格の表面粗さパラメータ ${ }^{32}$ によって破面を評価し た研究 ${ }^{20,21)}$ もみられる。例えば, 田嶋ら ${ }^{20)}$ は水セメント比と材齢が 破面と力学特性值に及ぼす影響を算術平均粗さ Ra で評価した。 Ra は表面性状パラメータの一つであり, 基準長さにおける高さの絶対 值の平均值である。また, 破面の凹凸を測定し 2 次元フーリエ変換 を行ってその周波数特性から破面の形態を特徵付けようとする研究

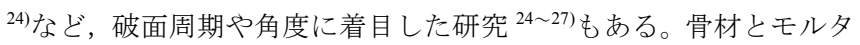
ルとの界面面積など構成要素の破壊面積率 $4,28-30)$ によって破面を評 価した研究も見られる。

著者ら ${ }^{22)}$ は新しい破面の特徴量として破面高さ分布の標準偏差 $\mathrm{Sd}$ に着目している。 $\mathrm{Sd}$ は全測定点に対する平均面からの高さの標 準偏差である。つまり, その面からの全測定点に対する二次モーメ ントの平方根である。その結果, 他の特徴量と同じく, Sd は力学特 性值と正の相関があることを示した。その他にも, 試験体の分離抵 抗性が破面局部の曲率半径に表れると予想し, 曲率半径に着目した 特徵量 $\operatorname{Rr}$ を提案した ${ }^{23)}$ 。

以上のレビューより, 線分割増率 $\mathrm{R}_{\mathrm{L}}$, 面積割増率 $\mathrm{R}_{\mathrm{S}}$, 走查線ᄀ ラクタル次元 $\mathrm{D}_{1}$, 面フラクタル次元 $\mathrm{D}_{2}$, 算術平均粗さ $\mathrm{Ra}$, 最大断 面高さ $\mathrm{Pt}$, また著者が提案した高さ分布の標準偏差 $\mathrm{Sd}$, 曲率半径の 分布割合 $\mathrm{Rr}$, 最大高さ $\mathrm{Hm}$ の合計 9 つの特徴量を, 破面解析の主要 特徵量として決定した。3 章以降の特徵量評価では, これら 9 つの 特徵量によって破面を評価していく。

\section{3. 実験}

\section{1 試験体作製}

破面解析の特徵量間の関係を調べるために，様々な条件を持つ試 験体で実験を行った。本研究では, 表 2 に示す 18 種類の調合を用い て梁型試験体を作製した。全ての調合でセメントは普通ポルトラン ドセメント(密度 $3.16 \mathrm{~g} / \mathrm{cm}^{3}$ )を使用し, 混和剤はメタクリル酸ポリマ 一高性能 AE 減水剂を使用した。粗粒率 FM は細骨材と粗骨材全体 の值であり，C，B493 や H494 が標準的な骨材粒度分布を持つ調合 である。表 3 に使用した骨材の名称と物性值を示す。

これら調合を用いて,一体打ち試験体と打継ぎ試験体を作製した。 すべての試験体寸法は，100×100×400mm の梁形とし，各水準 3 体ず

表 1 コンクリートの破面状態を示す定量的な特徵量

\begin{tabular}{|c|c|c|}
\hline & 特徵量の名称 & 主要文献 \\
\hline 割増率 & $\begin{array}{l}\text { 線分割増率 } \mathrm{R}_{\mathrm{L}} \\
\text { 面積割増率 } \mathrm{R}_{\mathrm{S}} \\
\end{array}$ & $\begin{array}{l}\text { 3) } \\
\text { 3), 4), 5), 6), 7), 8) }\end{array}$ \\
\hline $\begin{array}{l}\text { フラクタル } \\
\text { 次元 }\end{array}$ & $\begin{array}{l}\text { 線フラクタル次元 } \mathrm{D}_{1} \\
\text { 面フラクタル次元 } \mathrm{D}_{2}\end{array}$ & $\begin{array}{l}3), 4), 7), 9), 10), 11), 12), 13), 14) \\
4), 15), 16), 17), 18), 19)\end{array}$ \\
\hline 高さ分布 & $\begin{array}{l}\text { 算術平均粗さ } \operatorname{Ra}(\text { JIS規格) } \\
\text { 高さ分布の標準偏差 }\end{array}$ & $\begin{array}{l}20), 21) \\
22) \\
\end{array}$ \\
\hline 曲率半径 & 曲率半径の割合 $\mathrm{Rr}$ & 23) \\
\hline $\begin{array}{l}\text { 破面周期, } \\
\text { 角度 }\end{array}$ & $\begin{array}{l}\text { スペクトル } \\
\text { 確率密度分布 }\end{array}$ & $\begin{array}{l}24), 25) \\
26), 27)\end{array}$ \\
\hline $\begin{array}{l}\text { 構成要素の } \\
\text { 破懐面積率 }\end{array}$ & $\begin{array}{l}\text { 骨材界面面積率 } \\
\text { 骨材破壊面積率 } \\
\text { 破壊面積率 }\end{array}$ & $\begin{array}{l}\text { 4) } \\
\text { 28) } \\
\text { 29), 30) }\end{array}$ \\
\hline
\end{tabular}

表 2 調合表

\begin{tabular}{|c|c|c|c|c|c|c|}
\hline 調合名 & $\begin{array}{c}\mathrm{W} / \mathrm{C} \\
(\%) \\
\end{array}$ & $\begin{array}{l}\text { 骨材最大 } \\
\text { 粒径 (mm) }\end{array}$ & $\begin{array}{l}\text { 骨材量 } \\
\left(\mathrm{L} / \mathrm{m}^{3}\right) \\
\end{array}$ & $\begin{array}{c}\text { 粗粒率 } \\
\text { FM } \\
\end{array}$ & \begin{tabular}{|c}
$\begin{array}{l}\text { 圧縮強度 } \\
\left(\mathrm{N} / \mathrm{mm}^{2}\right)\end{array}$ \\
\end{tabular} & $\begin{array}{l}\text { 使用 } \\
\text { 骨材 } \\
\end{array}$ \\
\hline $\mathrm{C}$ & 51.4 & 25.0 & 706 & 4.93 & 42.0 & $\mathrm{~N}_{\mathrm{S}}, \mathrm{N}_{\mathrm{G}}$ \\
\hline S50 & 51.4 & 25.0 & 703 & 4.92 & 45.4 & $\mathrm{~N}_{\mathrm{S}}, \mathrm{N}_{\mathrm{G}}, \mathrm{S}_{\mathrm{S}}$ \\
\hline $\mathrm{S} 100$ & 51.4 & 25.0 & 700 & 4.94 & 46.3 & $\mathrm{~N}_{\mathrm{G}}, \mathrm{S}_{\mathrm{S}}$ \\
\hline B493 & 51.4 & 25.0 & 706 & 4.93 & 52.0 & \multirow{5}{*}{$\mathrm{N}_{\mathrm{S}}, \mathrm{N}_{\mathrm{G}}$} \\
\hline B524 & 51.4 & 25.0 & 706 & 5.24 & 52.8 & \\
\hline B456 & 51.4 & 25.0 & 706 & 4.56 & 50.8 & \\
\hline B422 & 51.4 & 25.0 & 706 & 4.22 & 37.3 & \\
\hline B356 & 51.4 & 10.0 & 706 & 3.56 & 42.1 & \\
\hline B234 & 51.4 & 5.0 & 526 & 2.34 & 58.9 & $\mathrm{~N}_{\mathrm{S}}^{*}$ \\
\hline H494 & 50.0 & 20.0 & 709 & 4.94 & 46.3 & \multirow{4}{*}{$\mathrm{H}_{\mathrm{S}}, \mathrm{H}_{\mathrm{G}}$} \\
\hline H528 & 50.0 & 20.0 & 709 & 5.28 & 45.1 & \\
\hline $\mathrm{H} 473$ & 50.0 & 20.0 & 709 & 4.73 & 46.5 & \\
\hline $\mathrm{H} 425$ & 50.0 & 20.0 & 709 & 4.25 & 43.0 & \\
\hline H263 & 50.0 & 5.0 & 512 & 2.63 & 47.5 & \multirow{4}{*}{$\mathrm{H}_{\mathrm{S}}^{*}$} \\
\hline H4 19 & 50.0 & 5.0 & 512 & 4.19 & 45.2 & \\
\hline H343 & 50.0 & 5.0 & 512 & 3.43 & 56.9 & \\
\hline $\mathrm{H} 188$ & 50.0 & 1.2 & 512 & 1.88 & 48.7 & \\
\hline CP 50 & 50.0 & - & 0 & - & 41.6 & 無し** \\
\hline
\end{tabular}

表 3 使用骨材

\begin{tabular}{l|r|r}
\hline \multicolumn{1}{c|}{ 骨材種類 } & $\begin{array}{r}\text { 表乾密度 } \\
\left(\mathrm{g} / \mathrm{cm}^{3}\right)\end{array}$ & $\begin{array}{c}\text { 吸水率 } \\
(\%)\end{array}$ \\
\hline $\mathrm{N}_{\mathrm{S}}$ : 秋田県産普通細骨材 & 2.49 & 1.97 \\
$\mathrm{~N}_{\mathrm{G}}$ : 秋田県産普通粗骨材(砕石) & 2.60 & 2.49 \\
$\mathrm{H}_{\mathrm{S}}$ : 埼玉県産高強度細骨材(硬質砂岩砕砂) & 2.64 & 1.48 \\
$\mathrm{H}_{\mathrm{G}}$ : 埼玉県産高強度粗,骨材(硬質砂岩砕石) & 2.68 & 1.01 \\
$\mathrm{~S}_{\mathrm{S}}$ : 高炉スラグ細骨材 & 2.64 & 1.09 \\
\hline
\end{tabular}




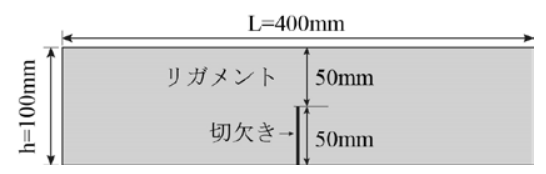

(a) 一体打ち試験体

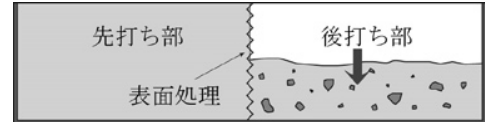

(b) 打継ぎ試験体

図 1 一体打ち試験体と打継ぎ試験体の寸法

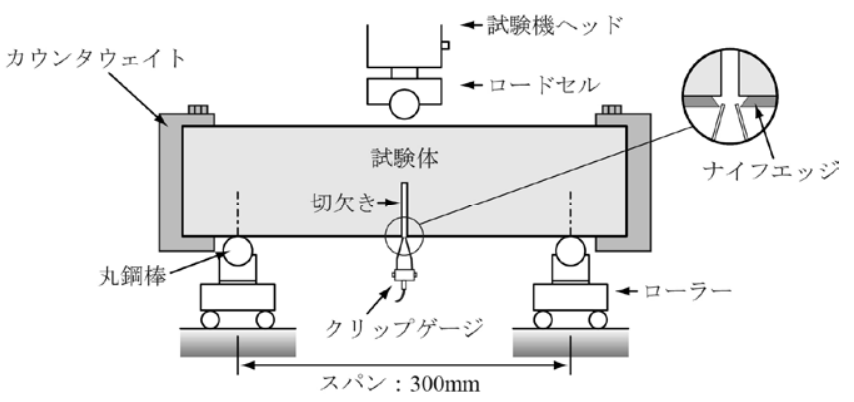

図 2 破壊勒性試験

つ作製した。打継ぎ試験体は, 先打ち部の打設および養生後に表面 処理を施し, 打継ぎを行った(図 1 参照)。表面処理として, 目荒し, 打継ぎシートなど複数種類を行ったが ${ }^{33)}$, 本稿ではまとめて打継ぎ 試験体として表示する。試験体作製方法の詳細は既報の論文 ${ }^{33)}$ に示 すとおりである。

\section{2 破壊勒性試験}

所定の水中養生後, 3 点曲げによる破壊勒性試験をスパン $300 \mathrm{~mm}$ で行い(図 2 参照), 荷重およびクリップゲージによる開口変位(以下, CMOD)を測定した。本研究ではスパン中央部に高さ $50 \mathrm{~mm}$ の切久き を入れ，また自重の影響を防ぐためカウンターウェイトを取付けて いる。なお, 力学特性として曲溞度 $\mathrm{Fb}$, 荷重-CMOD 曲線下の面 積から求められる破壊エネルギー $\mathrm{GF}_{(\mathrm{WOF})}$ を評価した ${ }^{23)}$ 。

\section{4. 破面解析}

\section{1 破面の測定}

破壊勒性試験後, 分離した破面を $1 \mathrm{~cm}$ 厚程度に切り出して絶乾後 デシケータで保存した。それら破面のリガメントに対して, レーザ 一光式の非接触三次元形状測定装置によって破面高さの測定を行っ た。レーザー光は $\mathrm{x}$ 方向に走查させ, 順次 $\mathrm{y}$ 方向の位置をずらすこ とで，破面全体を測定した。測定間隔は $\mathrm{x}, \mathrm{y}$ 方向ともに $50 \mu \mathrm{m}$ であ り, 三次元の座標を有する点群として記録される。測定によって得 られた三次元データは, 点群処理ソフトウェアによって, $200 \mu \mathrm{m}$ 間 隔に間引き，三角形のメッシュに変換した。三角形のメッシュに変 換することで図 3 に示寸破面の鳥瞰図が得られ，鳥瞰図をもとに破 面の高さ分布マップと曲率半径の分布マップを作成した。

また, 高さ分布に関する特徵量を求める際, 本研究で考慮した点 として，基準面の設定方法がある。試験体の多くは，粗骨材による ひび割れ偏向の影響を受けて, 図 4(a)のように切欠きの直上からは ずれた位置に破面が生じる。既往の研究は図 4(a)のように切欠き面

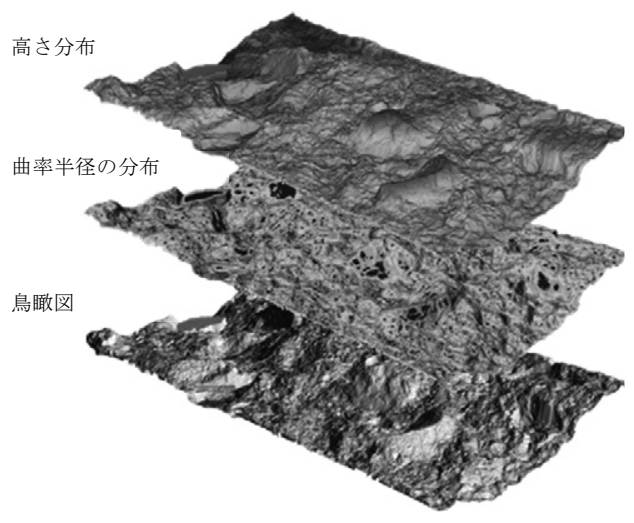

図 3 コンクリート破面のマップ

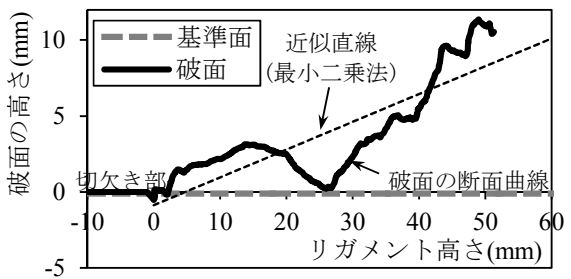

（a）切欠き面基準

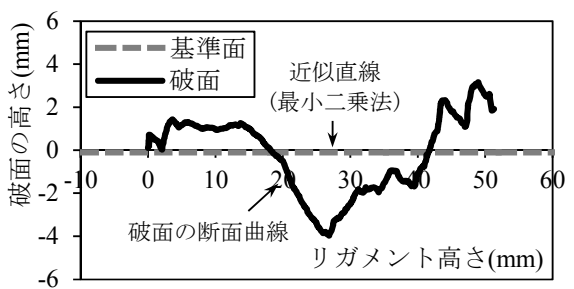

(b) 平均面基準

図 4 基準面の位置

を基準に破面の高さを算出しているが，本研究では図 4(b)に示すと おり，破面の平均面を基準面に用いる方法(ベストフィット)を採用 した。これは JIS 規格 ${ }^{32}$ の表面性状特徵量が, 実測の高さ分布から うねりを除いて粗さを算出しているのに着想を得たものである。リ ガメント部分のベストフィットによる平均面を基準にして，下記の 特徴量を求めた。

\section{2 破面の特徵量の算出}

本研究では破面の測定結果から得られたデータを元に，破面の特 徵量として 2 章で述べた 9 種, つまり (1)割増率 $\left(\mathrm{R}_{\mathrm{L}}, \mathrm{R}_{\mathrm{S}}\right),(2)$ フラク タル次元 $\left(\mathrm{D}_{1}, \mathrm{D}_{2}\right)$ ，(3)破面の高さ分布に関する特徴量 $(\mathrm{Ra}, \mathrm{Pt}, \mathrm{Hm}$, $\mathrm{Sd})$, (4)曲率半径の分布割合 $(\operatorname{Rr} 1)$ を求めた。以下に特徽量の求め方 を示す。なお，断面曲線は各破面につき 3 断面測定し，それらから 算出される特徵量の平均值を採用した。

\section{(1) 割増率}

線分割増率 $\mathrm{R}_{\mathrm{L}}$ は，図 5 に示すように実測の断面曲線長 $\mathrm{L}$ を投影 長さ $\mathrm{L}_{0}$ で除すること $\left(R_{L}=L / L_{0}\right)$ で求めた。同様に面積割増率 $\mathrm{R}_{\mathrm{S}}$ は 実測した破面の表面積 $\mathrm{S}$ を投影面積 $\mathrm{S}_{0}$ で除すること $\left(R_{S}=S / S_{0}\right)$ で求

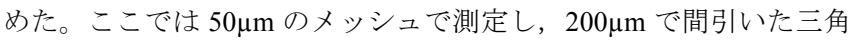
形メッシュの総面積を $\mathrm{S}$ としている。

\section{(2) フラクタル次元}

断面曲線を扱う走查線フラクタル次元 $\mathrm{D}_{1}$ の場合, 図 5 のデバイダ 
一法もしくはボックスカウンティング法で算出することができる。 本研究では, デバイダー法を用いてフラクタル次元 $\mathrm{D}_{1}$ を推定した 34, 35)。この時，フラクタル次元 $\mathrm{D}_{1}$ は(1)式で表すことができる。

$$
N(r)=k r^{-D_{1}}
$$

ここで $\mathrm{r}$ : 被覆するデバイダー線分長, $\mathrm{N}(\mathrm{r}) ： \mathrm{r}$ で被覆したときの デバイダー数, $\mathrm{k}$ : 正の定数, $\mathrm{D}_{1}$ : 走査線フラクタル次元である。

これらの式に従って, 段階的に $\mathrm{r}$ の長さを変えた $\mathrm{N}(\mathrm{r})$ の計測結果 を縦軸に, $\mathrm{r}$ を横軸に両対数グラフに描いた場合, 破面に自己相似 性があれば両者には一次の関係が得られる。この関係の勾配が走査 線のフラクタル次元 $\mathrm{D}_{1}$ に該当する。

また, 破面の表面積を扱う面フラクタル次元 $\mathrm{D}_{2}$ も断面曲線の場合 と同じで, 測定間隔 $\mathrm{r}$ を変えたメッシュで破面を被覆し(2)式で求め られる。

$$
S\left(r^{2}\right)=S_{0} \cdot\left(r^{2}\right)^{-\left(\frac{D_{2}-2}{2}\right)}
$$

ここで, $\mathrm{S}\left(\mathrm{r}^{2}\right)$ ：メッシュ間隔を $\mathrm{r}$ で測定した実面積, $\mathrm{S}_{0}$ ：投影面 積, $\mathrm{D}_{2}$ : 面フラクタル次元である。

\section{（3）JIS 規格の表面粗さ特徵量}

算術平均粗さ Ra は JIS 規格 ${ }^{32)}$ の表面性状特徵量の一つであり, 図 6 の基準長さ $(\mathrm{Lr})$ における高さの断面曲線 $(\mathrm{Z}(\mathrm{x}))$ の絶対值の平均值と して, (3)式として求められる。

$$
R a=\frac{1}{L_{r}} \int_{0}^{L_{r}}|Z(x)| d x
$$

また, 基準長さ $(\mathrm{Lr})$ における最高高さと最低高さの差が, 最大断 面高さ $\mathrm{Rz}($ 本稿では $\mathrm{Pt})$ である。

\section{（4）破面高さ分布の標準偏差 Sd}

高さ分布の標準偏差である $\mathrm{Sd}$ は, 破面高さ分布の確率密度関数 から導出が可能である。確率密度関数は基準面を基準にした場合の 高さ分布を水平投影面上に等間隔で測定して, 図 7 の模式図に示寸 ように破面全体として一つの確率密度関数を構成するように表した ものである。破面の高さ分布の分散 Var と標準偏差 Sd は次式で求め られる。

$$
\operatorname{Var}=\int_{-\infty}^{\infty}(y-\mu)^{2} f(y) d y, \quad s d=\sqrt{\operatorname{Var}}
$$

ここで, $\mathrm{y}$ : 平均面からの高さ, $\mu$ : 平均值, $\mathrm{f}(\mathrm{y})$ : 確率密度であ る。

また, 最大断面高さと同様の考えで, 破面全体の最高高さと最低 高さとの差を最大高さ $\mathrm{Hm}$ として定義することができる。

\section{(5) 曲率半径に関する特徵量の測定}

著者らは, 試験体の分離抵抗性が破面局部の曲率半径に表れると 予想し, 曲率半径に着目した特徴量を提案した。本研究で使用した プログラムでは, 測定点のメッシュ上で, 曲率半径 R を計算する点 を中心に正負方向に平均的に合計 11 点をとり二次曲線に近似し, 下 式から曲率半径 $\mathrm{R}$ を計算している。このとき $\mathrm{x}, \mathrm{y}$ 二方向について

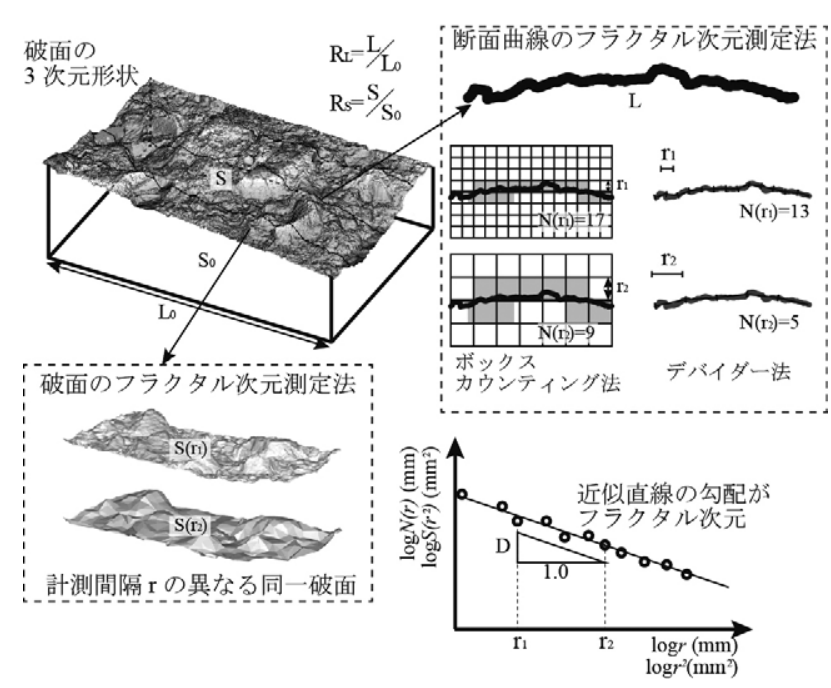

図 5 割増率とフラクタル次元の測定方法

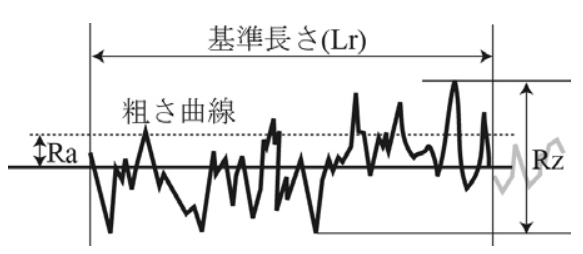

図 6 破面の粗さ曲線

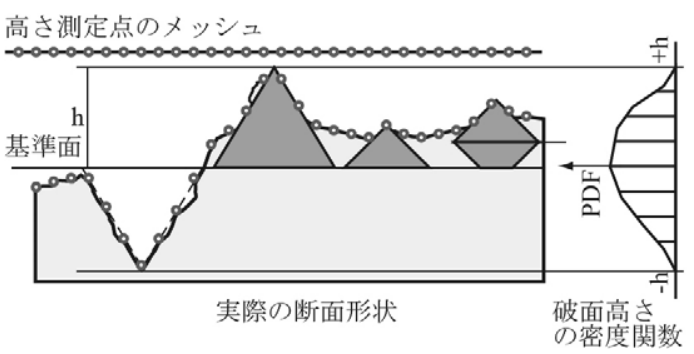

図 7 破面高さの確率密度関数

計算し，小さい方をその点の $\mathrm{R}$ とする。

$$
R=\left[1+\left(f^{\prime}(x)\right)^{2}\right]^{3 / 2} / f^{\prime \prime}(x)
$$

ここで, $\mathrm{R}$ : 曲率半径, $\mathrm{f}(\mathrm{x})$ : 近似曲線の関数である。

本研究では破面の微小な形状の曲率半径の分布を求め, 曲率半径 が $1 \mathrm{~mm}$ 以下の結果が破面全体に占める割合を Rr1 とした。

\section{5. 結果および考察}

\section{1 破面の特徵量と力学特性値との関係}

図 8 に破面の特徵量と曲治度 $\mathrm{Fb}$ との関係を, 同様に図 9 に破 面の特徵量と破壊エネルギー $\mathrm{GF}_{(\mathrm{WOF})}$ との関係を示す。図 8 と図 9 に は骨材の種類も異なり，また一体打ちと打継ぎ試験体の両方を含む が，それぞれの特徵量と相関関係があり，破面の特徴量が大きいほ ど力学特性值が高いことが判明した。 

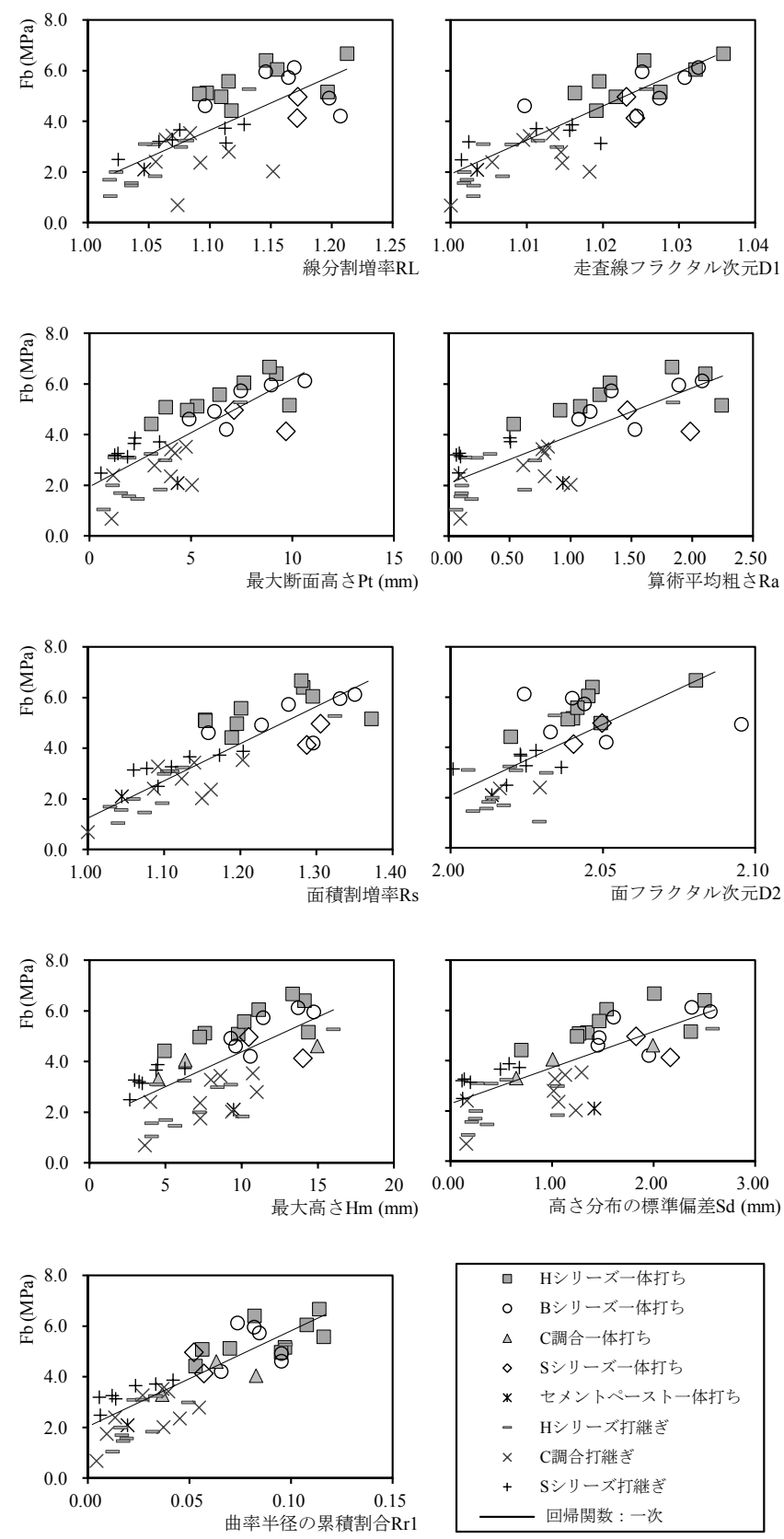

図 8 破面の特徴量と曲げ強度との関係

今回用いた試験体の一部を用いて行った断面内応力分布のモデル

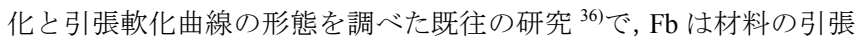
強度 $(\mathrm{Ft})$ と一次の比例関係にあり, $\mathrm{GF}_{(\mathrm{WOF})}$ は $\mathrm{Ft}$ と二次の比例関係に あることが示唆された。また, ひび割れの状態が複雑なほど破壊強 度に達した実面積が大きく Ft は大きいと考えられる。従って, Fb は各特徵量と一次関係の回帰関数を, $\mathrm{GF}_{(\mathrm{WOF})}$ は二次および確認のた めに一次の両方で回帰関数を計算した。さらに $\mathrm{Fb}$ と $\mathrm{GF}_{(\mathrm{WOF})}$ とも回 帰関数は原点を通らないと仮定している。これは例え, 平滑で特徴 量が 0 であっても化学的な結合力などで抵抗力は生じ, その結果 $\mathrm{GF}_{(\mathrm{WOF})}$ も生じると考えたためである。

図 8 と図 9 の相関係数を求めた結果を表 4 に示す。この時, $\mathrm{R}_{\mathrm{L}}$ と $\mathrm{D}_{1}$ は取り得る最小值が 1 であるため, 二次関数の頂点は $\mathrm{x}=1$ の軸上 にあるように決めた。同様に $\mathrm{D}_{2}$ は頂点が $\mathrm{x}=2$ の軸上にあるように
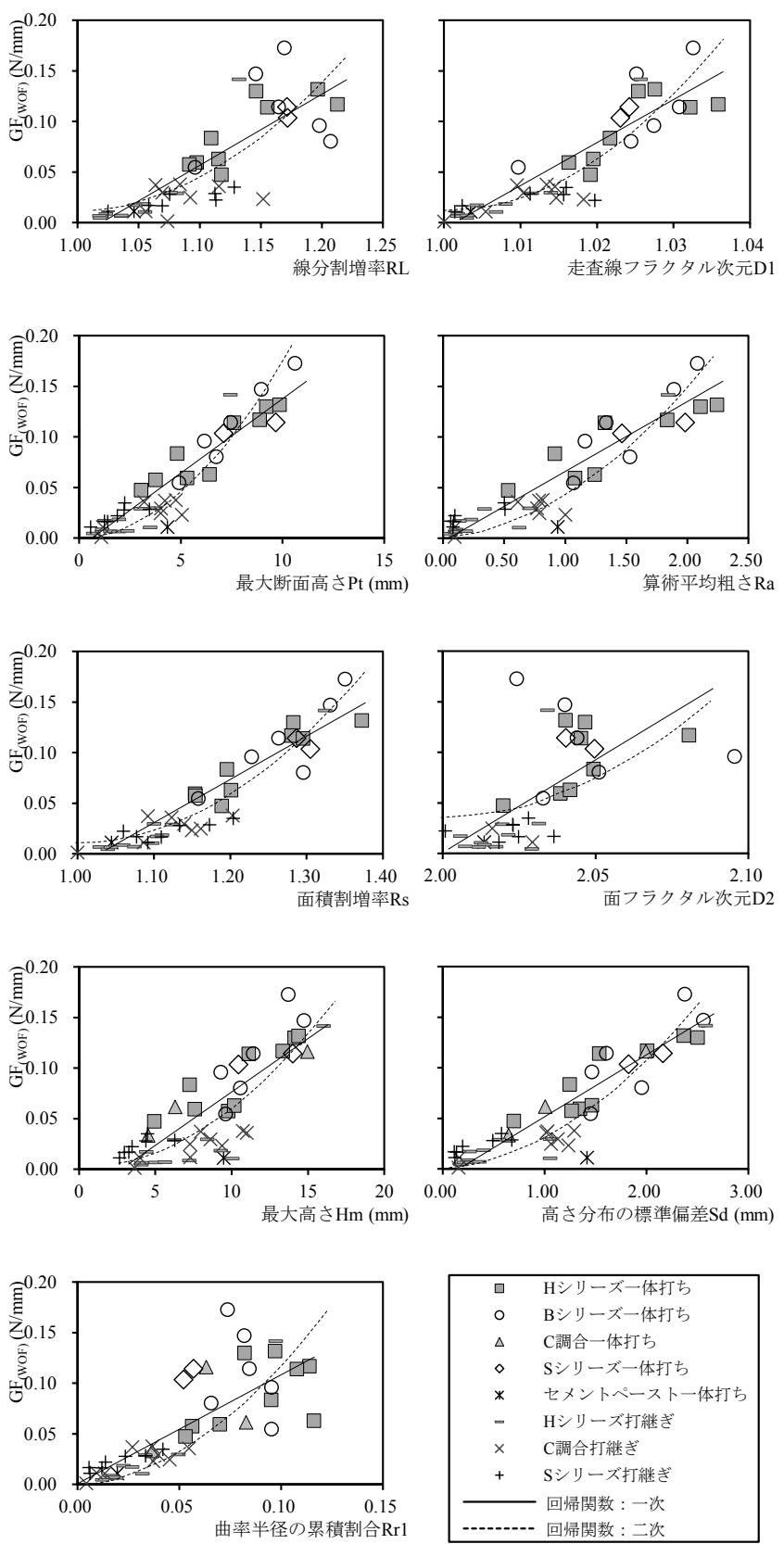

図 9 破面の特徴量と破壊エネルギーとの関係

決めた。破面の特徴量は断面線に関するものと全面に対するものに 分けられ，また高さに直接関係するものと高さに間接的に関係する ものに分けられるのでそのように分類して示寸。なお，ここで用い た相関係数は回帰曲線のカイ二乗を含む次式により計算した。

$$
\begin{gathered}
\chi^{2}=\sum_{i}\left(\frac{y_{i}-f\left(x_{i}\right)}{\sigma_{i}}\right)^{2} \\
R=\sqrt{1-\frac{\chi^{2}}{\sum_{i} \sigma_{i}\left(y_{i}-\bar{y}\right)^{2}}}
\end{gathered}
$$

ここで, $\chi^{2}$ : カイ二乗, $\left(\mathrm{x}_{\mathrm{i}}, \mathrm{y}_{\mathrm{i}}\right): \mathrm{i}$ 番目の $\mathrm{x}$ および $\mathrm{y}$ のデータポイ ントの值, $\sigma_{\mathrm{i}}$ : 重み(標準偏差), $\mathrm{R}$ : ピアソンの相関係数, $(\bar{x}, \bar{y}): \mathrm{x}$

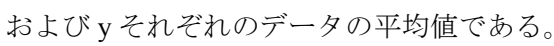


表 $4 \mathrm{Fb}$ および $\mathrm{GF}_{(\mathrm{WOF})}$ と破面解析特徵量との相関係数

\begin{tabular}{|c|c|c|c|c|c|c|c|c|c|c|}
\hline \multirow{3}{*}{ 対象 } & \multicolumn{4}{|c|}{ 断面線 } & \multicolumn{5}{|c|}{ 全面 } & \multirow{3}{*}{$\begin{array}{l}\text { 回帰 } \\
\text { 関数 }\end{array}$} \\
\hline & \multicolumn{2}{|c|}{ 高さ } & \multicolumn{2}{|c|}{ 高さに関係 } & \multicolumn{2}{|c|}{ 高さ } & \multicolumn{2}{|c|}{ 高さに関係 } & \multirow[b]{2}{*}{$\begin{array}{c}\text { Rr1 } \\
(-)\end{array}$} & \\
\hline & $\begin{array}{c}\mathrm{Pt} \\
(\mathrm{mm})\end{array}$ & $\begin{array}{c}\mathrm{Ra} \\
(\mathrm{mm})\end{array}$ & $\begin{array}{l}\mathrm{R}_{\mathrm{L}} \\
(-)\end{array}$ & $\begin{array}{l}D_{1} \\
(-)\end{array}$ & $\begin{array}{l}\mathrm{Hm} \\
(\mathrm{mm})\end{array}$ & $\begin{array}{c}\mathrm{Sd} \\
(\mathrm{mm})\end{array}$ & $\begin{array}{l}\mathrm{R}_{\mathrm{S}} \\
(-)\end{array}$ & $\begin{array}{l}\mathrm{D}_{2} \\
(-)\end{array}$ & & \\
\hline $\mathrm{Fb}$ & 0.793 & 0.795 & 0.751 & 0.868 & 0.647 & 0.760 & 0.851 & 0.670 & 0.836 & 一次 \\
\hline \multirow[t]{2}{*}{$\mathrm{GF}_{(\mathrm{WOF})}$} & 0.933 & 0.925 & 0.804 & 0.882 & 0.819 & 0.902 & 0.929 & 0.615 & 0.791 & 一次 \\
\hline & 0.935 & 0.919 & 0.771 & 0.882 & 0.851 & 0.916 & 0.932 & 0.481 & 0.722 & 二次 \\
\hline
\end{tabular}

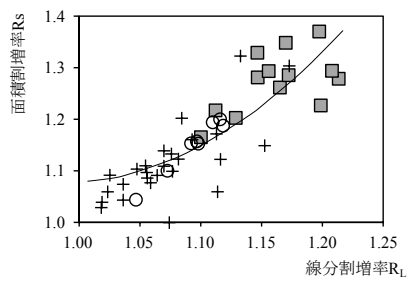

(a) $\mathrm{R}_{\mathrm{S}}-\mathrm{R}_{\mathrm{L}}$ 関係

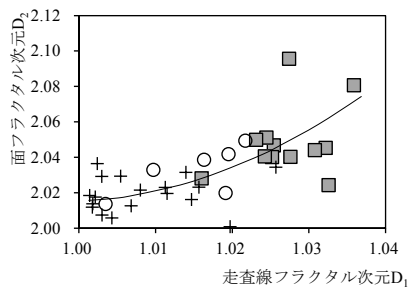

(c) $\mathrm{D}_{2}-\mathrm{D}_{1}$ 関係

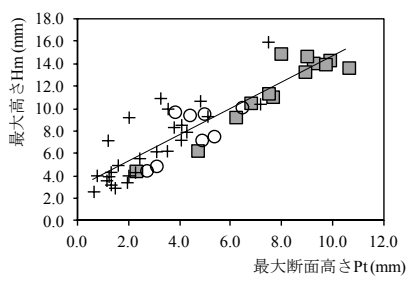

(b) Hm-Pt 関係

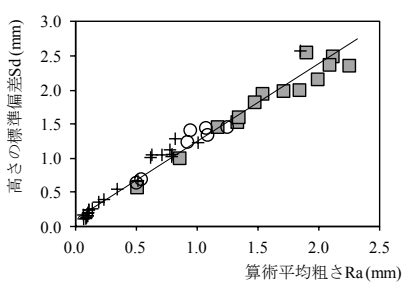

(d) Sd-Ra 関係
ロコンクリート一体打ち ○モルタル一体打ち +打継ぎ試験体

図 10 一次元と二次元の破面の特徴量間の関係

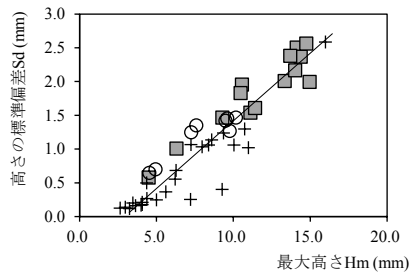

(a) Sd- Hm 関係

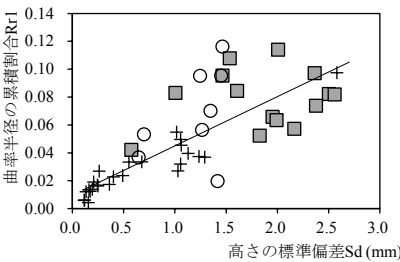

(c) Rr1-Sd 関倸

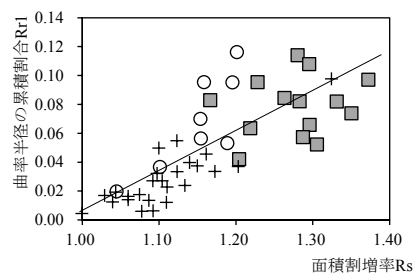

(e) $\operatorname{Rr} 1-\mathrm{R}_{\mathrm{S}}$ 関係

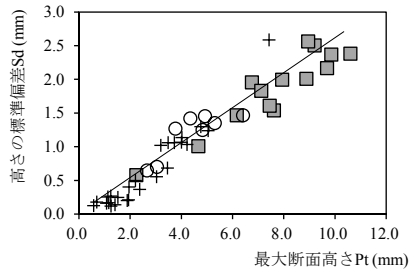

(b) Sd -Pt 関係

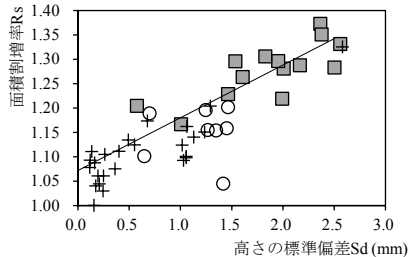

(d) $\quad \mathrm{R}_{\mathrm{S}} \mathrm{S} \mathrm{Sd}$ 関係

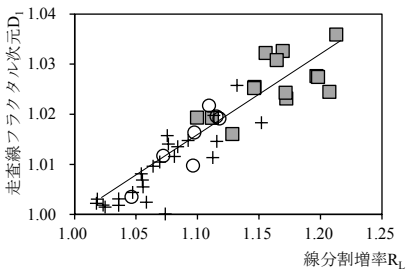

(f) $\mathrm{D}_{1}-\mathrm{R}_{\mathrm{L}}$ 関係

\begin{tabular}{l}
$\begin{array}{l}\text { ロコンクリート一体打ち ○モルタル一体打ち } \\
\text { +打継ぎ試験体 }\end{array}$ \\
\hline
\end{tabular}

図11 破面の特徵量間の関係
表 5 破面特徵量間の相関係数

\begin{tabular}{c|ccccccccc}
\hline & $\mathrm{Pt}$ & $\mathrm{Ra}$ & $\mathrm{R}_{\mathrm{L}}$ & $\mathrm{D}_{1}$ & $\mathrm{Hm}$ & $\mathrm{Sd}$ & $\mathrm{Rs}$ & $\mathrm{D}_{2}$ & $\mathrm{Rr} 1$ \\
\hline $\mathrm{Pt}$ & 1.000 & 0.986 & 0.821 & 0.859 & 0.897 & 0.962 & 0.898 & 0.595 & 0.801 \\
\hline $\mathrm{Ra}$ & & 1.000 & 0.808 & 0.838 & 0.912 & 0.985 & 0.899 & 0.591 & 0.797 \\
\hline $\mathrm{R}_{\mathrm{L}}$ & & & 1.000 & 0.918 & 0.657 & 0.765 & 0.865 & 0.727 & 0.745 \\
\hline $\mathrm{D}_{1}$ & & & & 1.000 & 0.700 & 0.797 & 0.890 & 0.666 & 0.829 \\
\hline $\mathrm{Hm}$ & & & & & 1.000 & 0.937 & 0.782 & 0.497 & 0.705 \\
\hline $\mathrm{Sd}$ & & & & & 1.000 & 0.874 & 0.565 & 0.789 \\
\hline $\mathrm{Rs}$ & & & & & & & 1.000 & 0.604 & 0.787 \\
\hline $\mathrm{D}_{2}$ & & & & & & & 1.000 & 0.708 \\
\hline $\mathrm{Rr} 1$ & & 1 & & & & & & & 1.000 \\
\hline
\end{tabular}

$\mathrm{D}_{1}-\mathrm{D}_{2}, \mathrm{R}_{\mathrm{L}}-\mathrm{R}_{\mathrm{S}}$ だけは二次関数で回帰，他は一次関数で回帰

表 4 から $\mathrm{GF}_{(\mathrm{WOF})}$ の相関係数が $\mathrm{Fb}$ のそれよりも全体的に高めであ ることが分かる。 $\mathrm{GF}_{(\mathrm{WOF})}$ が内部欠陥の分布状態で影響を受ける結果, 破面の特徵量に現れるのに対して, 強度は内部欠陥の分布状態より もその大きさによって影響を受けると考えるとこの傾向は理解でき る。また $\mathrm{GF}_{(\mathrm{WOF})}$ では近似関数が一次でも二次でも， $\mathrm{D}_{2}$ を除いて相 関係数は大差ないことが分かる。 $\mathrm{D}_{2}$ では(2)式から分かるように面積 に関する特徴量であるため，さらに二次関数で近似することは意味 がないことを示している。

\section{2 破面の特徵量間の関係}

\section{(1) 一次元特徵量と二次元特徵量間の関係}

図 10 は一次元特徴量と二次元特徴量間の関係について見たもの である。 $\mathrm{R}_{\mathrm{S}}-\mathrm{R}_{\mathrm{L}}$ 関係は予想されるように二次の関係である。 $\mathrm{Hm}-\mathrm{Pt}$ の関係は，一対一の対応からずれており，断面線が必ずしも最大高 さの部分を含んでいないことを示している。 $\mathrm{D}_{2}-\mathrm{D}_{1}$ 関係はきわめて 曖昧であるが, これは表 4 にも現れているように $\mathrm{D}_{2}$ がばらついてい るためである。本研究では破面が小さいため $(50 \mathrm{~mm} \times 100 \mathrm{~mm}), 5 \mathrm{~mm}$ 〜 200 $\mu \mathrm{m}$ 程度の範囲，つまり細骨材の範囲でフラクタル次元を確定 した。そのため，三種類用いた細骨材の違いの影響を他の特徴量よ りも大きく受けたと考えられる。なお $\mathrm{Sd}$ と Ra には極めて強い一時 関係 $(\mathrm{Sd}=\mathrm{Ra} / 0.87)$ が認められる。これは破面の形状モデルを用いて 解析的に説明できるが，続報に譲る。

\section{(2) 主要特徵量間の関係}

図 11 は代表的な破面の特徵量間の関係を示す。また, 全ての破面 の特徴量間の相関係数を計算した結果を表 5 に示す。ここでは前項 と同じ理由により $\mathrm{R}_{\mathrm{S}}-\mathrm{R}_{\mathrm{L}}$ 関係は $\mathrm{x}=1$ の軸上に頂点がある二次関数で 回帰した。また $\mathrm{D}_{2}-\mathrm{D}_{1}$ 関係は物理的な意味が曖昧であるが一次関数 よりも二次関数の方で相関係数がわずかに高かったので，同様な二 次関数で相関係数を求めた。他の関係は一次関数で回帰している。 これから Sd-Hm や Sd-Pt 間のように，高さの特徵量同士の間には強 い相関関係がある。一方で，本研究では骨材の種類が様々であるた め，骨材のエッジを対象とする Rr1 では全体的に他の特徵量との相 関係数が小さい。また，Ptや $\mathrm{Hm}$ のようなピークだけの值ではなく 統計処理を行った Ra や Sd で相関係数が高くなっていることが分か る。図 11(f)は $D_{1}-R_{L}$ 関係である。既往の研究 ${ }^{4)}$ も示されたように $\mathrm{D}_{1}-\mathrm{R}_{\mathrm{L}}$ には強い相関関係がある。 $\mathrm{D}_{1}-\mathrm{D}_{2}$ の関係は前述の理由により $\mathrm{D}_{2}$ のばらつきが大きかったが，いずれにしても表 5 に掲げる特徴量 同士は，程度の差はあるがお互いに密接な関係にあると言える。

\section{3 破面解析特徵量の意義}

著者が考察してきた 9 種類の破面特徵量を分類すると表 6 に示す 
表 6 破面特徵量の分類

\begin{tabular}{c|c|c|c|c|c}
\hline \multirow{2}{*}{ 対象 } & \multicolumn{4}{|c}{ 破壊した経路とその影響範囲 } \\
\cline { 2 - 6 } & \multicolumn{2}{|c|}{ 到達点 } & \multicolumn{2}{|c}{ 増加 } & 局所 \\
\cline { 2 - 6 } & 高さ & 統計量 & 増加率 & $\begin{array}{c}\text { 増加 } \\
\text { 傾向 }\end{array}$ & 曲率 \\
\hline 断面曲線 & $\mathrm{Pt}$ & $\mathrm{Ra}$ & $\mathrm{R}_{\mathrm{L}}$ & $\mathrm{D}_{1}$ & \\
\hline 全破面 & $\mathrm{Hm}$ & $\mathrm{Sd}$ & $\mathrm{R}_{\mathrm{S}}$ & $\mathrm{D}_{2}$ & $\mathrm{Rr} 1$ \\
\hline
\end{tabular}

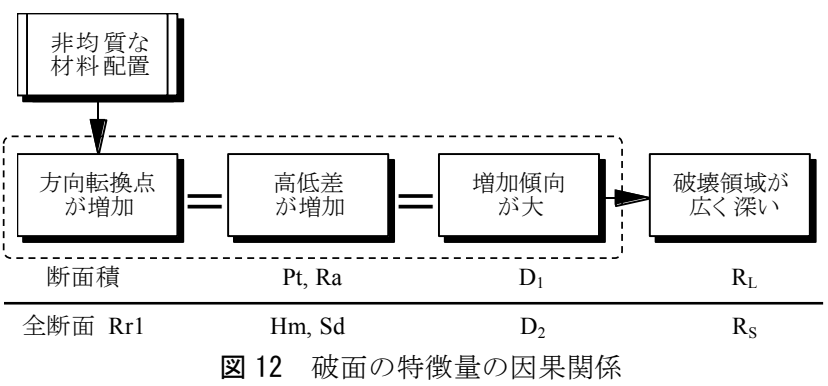

とおりである。高さに着目した特徵量では, 異常值を排除できる Ra や Sd が改善された特徵量で, 表 4 に示寸力学特性值との相関係数 の高さに現れている。それらは破壊進展経路の最大到達点(高さ)に 着目したものであるのに対し, 微分的な視点から断面線や面積の増 加率に着目した $\mathrm{R}_{\mathrm{L}}$ や $\mathrm{R}_{\mathrm{S}}$ が存在する。それらがデバイダー長さを変 えることによって変化するのに対して, 増加の傾向を一つの特徵量 に置き換えたフラクタル次元があり, 表 4 に見るようにこれらの中 には Raや Sd よりも力学特性值との相関係数の高いものがある。特 に破面面積の増加率 $\mathrm{R}_{\mathrm{S}}$ は $\mathrm{Fb}$ にも $\mathrm{GF}_{(\mathrm{WOF})}$ にも相関係数が高く, 注目 される。

以上の考察をもとに破面特徴量と力学特性值との因果関係を推定 すると, 図 12 のように表される。つまりコンクリートの非均質性に 由来してひび割れは方向転換が多くなることで破面の高低差は高く なり，それに伴い破面の長さや面積の増加傾向が大きくなり，最終 的に破面に現れる実長や面積が大きくなるのである。それぞれに対 応して破面特徴量が計算されていると考えることが出来る。最終的 に破壊した領域が広ければ投影面積当たりの強度が高く, 破壊進行 領域が広いことを意味し, 破壊表面積の増加に伴う消散エネルギー の増大により $\mathrm{GF}_{(\mathrm{WOF})}$ が高くなると考えられる。断面線を対象にする よりも，全破面を対象にした特徴量が適切であることは当然考えら れる。つまり, $\mathrm{R}_{\mathrm{S}}$ が力学特性值に最も近い特徵量と推定され, 表 4 でも $\mathrm{R}_{\mathrm{s}}$ において力学特性值との相関係数が高い結果となっている。 フラクタル次元もフラクタル性がデバイダー長に拘わらず全領域で 成立すれば同じ結果となると考えられるが, 本研究のように骨材最 大粒径に比して小さい領域を対象にした場合，多種多様のコンクリ 一ト破面では結果的にフラクタル性の推定に困難を来たして, $\mathrm{D}_{2}$ の 推定に大きな誤差を生じ, 相関係数が小さくなってしまう場合もあ る。

\section{6. 結論}

本研究ではコンクリートの破面解析に用いられる 9 種類の特徵量 と力学特性值との関係を実験的に考察した。試験体に用いたコンク リートは, 骨材量と骨材の最大粒径, 銘柄, 粗粒率が異なり, 水セ
メント比が $50 \%$ 程度の 18 水準であり, その中にはセメントペース ト，モルタルも含んでいる。また試験体は一体打ちだけではなく， 打継ぎを行ったものも含まれている。そのような多種多様なコンク リートの破壊鞋性試験と破面解析を行い, 力学特性值と破面解析特 徵量を算出した。その結果, 下記の点が明らかになった。

（1）９種類の特徵量は，高さという到達点に着目するか，投影長さ や投影面積からの増加に着目寸るか，局所的な曲率に注目寸るかの 違いだけではあるが，結局破壊した経路とその影響範囲を表してい るため，お互いは密接な関係にある。

(2) コンクリートの非均質性に由来するひび割れ伸展経路とその 影響範囲の広がりは，検討した特徵量の中では，最終的に破面の面 積増加率 $\left(\mathrm{R}_{\mathrm{S}}\right)$ でより良く表され, 本研究では力学特性値と最も対応 が良かった。

なお，本論文の破面解析は，試験体ごとに異なる破面を一般化し て定量值(破面特徵量)とし，それと力学特性值とが間接的な相関関 倸にあるということを示すものである。つまりそこでは，ひび割れ 伸展の過程の考察は出来ず，また特徵量に対して力学特性值を直接 的に結びつけられない。しかし，著者は続報においてコンクリート の非均質性を一般的なモデルに表して有限要素解析することで, 破 面解析の拡張を試みる予定である。

\section{謝辞}

本論文の最後のまとめにあたり, 熊本大学・村上聖教授にご指導 を頂いた。さらに，本論文の基となる筆頭著者の学位論文執筆にあ たり, 岐阜大学・六郷恵哲教授, 秋田県立大学・小林淳教授, 東北 大学・三橋博三名誉教授にご援助を頂いた。ここに記して感謝の意 を表す。

\section{参考文献}

1) 小寺沢良一：フラクトグラフィ(1)(破面解析), 材料, Vol.23, No.248, pp.412-421，1974.5

2）三橋博三，梅岡俊治，三浦悟：セメント硬化体の破面解析に関する基 礎的研究，日本建築学会構造系論文報告集 No.445, pp.19-25, 1993.3

3) G. Prokopski and B. Langier: Effect of water/cement ratio and silica fume addition on the fracture toughness and morphology of fractured surfaces of gravel concretes, Cement and Concrete Research, Vol. 30, No. 9, pp. 1427-1433, 2000

4) 三橋博三 : 骨材粒径を変えたコンクリートの破面解析，日本建築学会 構造系論文報告集，第 453 号, pp. 1-7, 1993.11

5) D. Zampini, H. M. Jennings and S. P. Shah: Characterization of the paste-aggregate interfacial transition zone surface roughness and its relationship to the fracture toughness of concrete, Journal of Materials Science, Vol. 30, No. 12, pp. 3149-3154, 1995

6) T. Ficker, D. Martišek and H. M. Jennings: Roughness of fracture surfaces and compressive strength of hydrated cement pastes, Cement and Concrete Research, Vol. 40, No. 6, pp. 947-955, 2010

7) 国枝稔，林承燦，鎌田敏郎，六郷恵哲，栗原哲彦：コンクリートの破 断面の表面積とフラクタル次元, 土木学会年次学術講演会講演概要集 第 5 部，Vol. 52，pp. 720-721，1997

8) P. Chupanit and J. R. Roesler: Fracture energy approach to characterize concrete crack surface roughness and shear stiffness, Journal of Materials in Civil Engineering, Vol. 20, No. 275, pp. 275-282, 2008

9) L. T. Dougan and P. S. Addison: Estimating the cut-off in the fractal scaling 
of fractured concrete, Cement and Concrete Research, Vol. 31, No. 7, pp. 1043-1048, 2001

10) V. E. Saouma, C. C. Barton and N. A. Gamaleldin: Fractal characterization of fracture surfaces in concrete, Engineering fracture Mechanics, Vol. 35, No. 1-3, pp. 47-53, 1990

11) M. A. Issa, A. M. Hammad and A. Chudnovsky: Correlation between crack tortuosity and fracture toughness in cementitious material, International Journal of Fracture, Vol. 60, No. 2, pp. 97-105, 1993

12) B. Chiaia, J. G. M. van Mier and A. Vervuurt: Crack growth mechanisms in four different concretes:Microscopic observations and fractal analysis, Cement and Concrete Research, Vol. 28, No. 1, pp. 103-114, 1998

13) K. Wu, A. Yan, J. Liu, D. Zhang and W. Yao: Reconstruction and analysis of 3-D profile of fracture surface of concrete, Cement and Concrete Research, Vol. 30, No. 6, pp. 981-987, 2000

14) L. Czarnecki, A. Garbacza and J. Kurach: On the characterization of polymer concrete fracture surface, Cement and Concrete Composites, Vol. 23, No. 4-5, pp. 399-409, 2001

15) Y. Wang and S. Diamond: A fractal study of the fracture surfaces of cement pastes and mortars using a stereoscopic SEM method, Cement and Concrete Research, Vol. 31, No. 10, pp. 1385-1392, 2001

16) M. A. Issa, M. A. Issa, M. S. Islam and A. Chudnovsky: Fractal dimension - a measure of fracture roughness and toughness of concrete, Engineering fracture Mechanics, Vol. 70, No. 1, pp. 125-137, 2003

17) A. Yan, K. Wu, D. Zhang and W. Yao: Influence of concrete composition on the characterization of fracture surface, Cement and Concrete Composites, Vol. 25, No. 1, pp. 153-157, 2003

18) Y. -S. Roh and Y. Xi: The fracture surface roughness of concrete with different aggregate sizes and loading rates, American Concrete Institute Special Publication, Vol. 201, pp. 35-54, 2001

19) V. Mechtcherine: Fracture mechanical behavior of concrete and the condition of its fracture surface, Cement and Concrete Research, Vol. 39, No. 7, pp. 620-628, 2009

20)田嶋和樹, 白井伸明, 森泉和人, 渡部憲 : 水セメント比と材齢の異な るコンクリートの引張軟化特性, コンクリート工学年次論文集, Vol. 24, No. 2, pp. $169-174,2002$

21) 安江正文, 金子林爾 : 各種高強度コンクリートの水平打継ぎ面粗さが 破壊特性に及ぼす影響 その 2 : 引張軟化曲線による評価と供試体破断 面のフラクトグラフィー, 日本建築学会東海支部研究報告集, 第 42 号, pp. 141-144, 2004

22）佐藤あゆみ, 山田寛次, 石山智: 破面解析に基づく高さの確率密度関 数を用いた新旧コンクリート界面における機械的性質の新しい評価指 標, 日本建築学会構造系論文集, 第 75 巻, 第 655 号, pp1587-1594, 2010.9

23）佐藤あゆみ, 山田寛次, 石山智 : 高炉スラグ細骨材を用いたコンクリ 一トの打継ぎ界面の力学特性值と破面特徴量との関係, コンクリート 工学年次論文報告集, Vol.32, No.2, pp.55-60, 2010

24）佐藤良介, 和田俊良, 上田正生： 2 次元フーリエ変換を用いたコンク リート亀裂面の形状解析手法の開発一コンクリート亀裂面の周波数特 性に関する解析的研究 その 1 -, 日本建築学会構造系論文集, 第 589 号, pp. 105-112, 2005.3

25) 中村裕, 三橋博三 : コンクリート破面特性の定量的評価方法に関する 研究, 日本建築学会大会学術講演梗概集 A-1 材料施工, pp. 989-990, 1995

26) 和田俊良, 佐藤龍司, 石川千温, 上田正生 : レーザビーム光線による 亀裂面形状測定手法の開発とデータの 2 次元分析手法の提案ーコンク リート亀裂面の形状特性分析に関する基礎的研究 (その 1)-, 日本建 築学会構造系論文集, 第 490 号, pp. 179-188, 1996.12

27) 岡村甫, 前川宏一: 鉄筋コンクリートの非線形解析と構成則, 技報堂
出版, 182pages, 1991

28) K. Wu, J. Liu, D. Zhang and A. Yan: Rupture probability of coarse aggregate on fracture surface of concrete, Cement and Concrete Research, Vol. 29, No. 12, pp. 1983-1987, 1999

29) A. B. Nichols and D. A. Lange: 3D surface image analysis for fracture modeling of cement-based materials, Cement and Concrete Research, Vol. 36, No. 6, pp. 1098-1107, 2006

30) 辻幸和, 古沢政夫, 長谷川幹央, 森脇貴志 : ポリマーセメントモルタ ルを用いた新旧コンクリートの打継目施工，コンクリート工学年次論 文報告集，第 11 号， 1 巻, pp. 721-726, 1989

31) B. B. Mandelbrot, D. E. Passoja and A. J. Paullay: Fractal character of fracture surfaces of metals, Nature, Vol. 308, pp. 721-722, 1984

32) 日本規格協会編：JIS B 0601(2001), 製品の幾何特性仕様(GPS)

33) 佐藤あゆみ, 山田寬次, 石山智: 引張軟化曲線と引抜だぼモデルによ る新旧コンクリート界面の強度と勒性の関係についての考察, 日本建 築学会構造系論文集, 第 74 巻, 第 637 号, pp. 417-424, 2009.3

34) 高安秀樹：フラクタル, 朝倉書店, 186pages, 1986

35) 石村貞夫, 石村園子 : フラクタル数学, 東京図書, 259pages, 1990

36) 佐藤あゆみ, 山田寛次, 石山智 : 鉛直打継ぎ面をもつコンクリート梁 の断面内応力分布モデルの提案, コンクリート工学年次論文報告集, Vol. 30, No. 1, pp. 399-404, 2008

(2013年 9 月 9 日原稿受理, 2014年 1 月 8 日採用決定) 